\title{
Perancangan Aplikasi Sosiometri Pada Rumah Sakit Bhayangkara Mayang Mangurai Jambi
}

\author{
$\underline{\text { Ari Andrianti }}$ \\ Sistem Informasi, Fakultas Ilmu Komputer, Universitas Dinamika Bangsa \\ Jalan Jend Sudirman Thehok, Kota Jambi, Indonesia \\ ariandrianti@gmail.com
}

\begin{abstract}
Social conditions in the work environment at Bhayangkara Jambi Hospital with a significant number of employees, especially relations between fellow employees are not always harmonious. This kind of thing can have a negative impact on performance appraisal. Realizing the important role of harmonious social interaction, it is necessary to design an application with a method and instrument called sociometry. The design of this application uses the waterfall model wherein this model starts from the requirements analysis, system design, unit implementation and testing and system testing. This research resulted in a sociometric application so that with this application the problems of work relations and employee performance appraisal can be solved.
\end{abstract}

Keywords: design, sociometric instruments, sociometric applications

\begin{abstract}
Abstrak
Kondisi sosial di lingkungan kerja di RS Bhayangkara Jambi dengan jumlah pegawai yang cukup banyak khususnya hubungan antar sesama pegawai tidaklah selalu harmonis. Hal semacam ini bisa memberikan dampak negatif terhadap penilaian kinerja Menyadari pentingnya peranan interaksi sosial yang harmonis, maka perlu dirancang sebuah aplikasi dengan metode dan instrument yang dinamakan sosiometri. Perancangan aplikasi ini menggunakan model waterfall dimana dalam model ini dimulai dari tahap analisis kebutuhan, desain sistem, implementasi dan pengujian unit serta pengujian sistem. Penelitian ini menghasilkan sebuah aplikasi sosiometri sehingga dengan adanya aplikasi ini maka permasalahan hubungan kerja dan penilaian kinerja pegawai dapat di atasi.
\end{abstract}

Kata kunci: perancangan, instrumen sosiometri, aplikasi sosiometri

\section{Pendahuluan}

Sosiometri adalah salah satu cara untuk mengukur tingkat hubungan sosial antar individu [1]. Sosiometri dapat diartikan juga sebagai suatu metode pengumpulan serta analisis data mengenai pilihan, komunikasi dan pola interaksi antara individu dalam kelompok [2]. Kelebihan dari metode sosiometri adalah: teknik ini relatif sederhana, dilaksanakan berdasarkan pada pilihan individu kepada rekannya dalam beberapa situasi kelompok atau aktivitas. Memberikan informasi yang akurat tentang alasan seorang individu dipilih dan/atau ditolak oleh rekannya. Memberikan kesempatan kepada konselor untuk melakukan analisis secara kualitatif dan/atau kuantitatif. [3].

Sosiometri dapat dipergunakan untuk memperbaiki hubungan insani, menentukan kelompok kerja, meneliti kemampuan memimpin seseorang individu dalam kelompok tertentu, mengetahui bagaimana hubungan sosial/berteman seorang individu dengan individu lainnya, mencoba mengenali problem penyesuaian diri seorang individu dalam kelompok sosial tertentu dan menemukan individu mana yang diterima/ditolak dalam kelompok sosial tertentu [4]. Sosiometri juga dapat digunakan untuk pengembangan organisasi/perusahaan. Dengan sosiometri, anggota kelompok/grup dapat memahami sendiri secara obyektif dan melakukan analisis dinamika kelompok sehingga sosiometri merupakan alat yang ampuh untuk mereduksi konflik dan meningkatkan komunikasi antar individu dalam perusahaan [5].

Rumah Sakit Bhayangkara Jambi sebagai salah satu rumah sakit milik pemerintah yang memberikan pelayanan kesehatan kepada masyarakat umum dalam hal ini dibawah kendali Institusi POLRI memiliki jumlah pegawai sebanyak 335 orang. Lingkungan kerja sebagai tempat untuk saling berinteraksi antar 
sesama pegawai dalam melakukan pekerjaannya seringkali kondisi sosial di lingkungan kerja dengan jumlah pegawai yang cukup banyak khususnya hubungan antar sesama pegawai tidaklah selalu harmonis. Hal semacam ini bisa memberikan dampak negatif terhadap penilaian kinerja. Menyadari pentingnya peranan interaksi sosial yang harmonis, maka perlu dirancang sebuah aplikasi dengan metode dan instrument yang dinamakan sosiometri.

Beberapa penelitian yang telah dilakukan dengan menggunakan instrument sosiometri yang dijadikan referensi dalam penelitian ini adalah: Penelitian yang dilakukan oleh Eri Purwanti, Eddy Purnomo dan Pujiati dengan judul Pengembangan Instrumen Keterampilan Sosial Berbasis Observasi dan Sosiometri dalam Pembelajaran IPS. Produk yang dihasilkan dalam penelitian ini adalah instrument keterampilan social. Semua item pernyataan dalam instrument pengembangan dinyatakan valid yaitu 24 item valid semua, instrument sebelum pengembangan tidak valid 8 item pernyataan. Produk instrumen keterampilan sosial berbasis observasi dan sosiometri yang telah dihasilkan dapat digunakan sebagai instrumen dalam proses pembelajaran di sekolah menengah pertama pada umumnya, Penggunaan instrumen keterampilan sosial masih dapat disempurnakan atau dikembangkan sesuai dengan indikator yang akan diukur pada diri siswa disekolah masing-masing [6].

Berdasarkan penelitian yang dilakukan oleh Rochani, Raudah Zaimah Dalimunthe dan Bangun Yoga Wibowo dengan judul Penggunaan Software Sosiometri Untuk Eksplorasi Kematangan Sosial pada Mata Kuliah Asesment Non Tes. Untuk lebih mengefektifkan proses perkuliahan maka akan disusun suatu inovasi pembelajaran yaitu dengan mengembangkan instrumen manual sosiometri menjadi berbantuan aplikasi software sosiometri. Tujuan penelitian ini merupakan penelitian pengembangan dengan tahapan pra pelaksanaan, pelaksanaan non tes, analisis, dan evaluasi aplikasi software non tes. Instrumen yang digunakan telah tervaliditas.. Selain itu, penggunaan software sosiometri ini dalam perkuliahan asesmen psikologi teknik non tes dapat mengembangkan kemandirian belajar mahasiswa. Hasil penelitian menunjukkan bahwa kematangan sosial mahasiswa dalam interaksi di bidang sosial, pribadi, belajar, dan karir masih di kategori rendah.[7] .

Berdasarkan penelitian yang dilakukan oleh Akhmad, Abdul dan Anas Malik dengan Judul Pengembangan Program Sosiometri Sebagai Media Pengungkapan Hubungan Sosial Siswa SMAN9 Makassar. Program sosiometri pada siswa SMA harus bisa mengantar setiap pelajar untuk menciptakan hubungan sosial yang optimal sebab mengingat remaja SMA mereka berada pada fase transisi dari dunia anak ke dunia dewasa. Mereka harus menggunakan masa remajanya untuk bersiap melakukan berbagai peran yang harus dilaksanakan pada masa dewasanya. Program sosiometri sebagai media pengungkapan hubungan sosial siswa yang dikembangkan ini, merujuk pada kebutuhan siswa itu sendiri dan merujuk pada hubungan sosial siswa yang satu dan lainnya. Dengan merujuk kepada tahapan pelaksanaan Esosiometri, maka kebutuhan dalam menciptakan hubungan sosial dapat optimal [8]. Berkaitan dengan uraian diatas maka pada artikel ini peneliti akan membahas tentang perancangan aplikasi sosiometri pada Rumah Sakit Bhayangkara Mayang Mangurai Jambi.

\section{Metodologi}

Dalam penelitian ini penulis melakukan langkah-langkah sebagai berikut:

1. Studi Pendahuluan

Studi pendahuluan ini merupakan awal dari kegiatan penelitian yang bertujuan untuk mengidentifikasi dan merumuskan masalah-masalah yang terjadi pada proses interaksi sosial pada RS Bhayangkara Jambi serta mencari masukan-masukan yang diperlukan untuk merancang dan membangun aplikasi sosiometri.

2. Studi literatur

Studi literatur ini dilakukan untuk mencari literatur-literatur yang berkaitan dengan tema penelitian baik itu dari buku maupun penelitian-penelitian terdahulu sehingga dalam pembangunan aplikasi sosiometri ini penulis memiliki referensi-referensi yang baik.

3. Pengumpulan data

Pengumpulan data pada penelitian ini dilakukan melalui beberapa cara, yang pertama melalui observasi atau pengamatan langsung di RS Bhayangkara Jambi, yang kedua melalui wawancara dan yang terakhir mengumpulkan dokumen-dokumen yang berkaitan dengan proses sosiometri.

4. Analisa Kebutuhan sistem

Analisa kebutuhan sistem ini penulis lakukan dengan mempelajari dan menganalisa dokumendokumen yang telah di kumpulkan serta proses yang sedang berlangsung. 
5. Desain Sistem.

Pada tahap desain sistem ini hal pertama yang dilakukan melakukan pemodelan terhadap sistem dengan dengan menggunakan use case diagram, activity diagram serta class diagram. Setelah itu dilanjutkan dengan desain input dan output lalu serta pembangunan aplikasi dengan menggunakan bahasa pemrograman php dan mengguanan DBMS MySql.

\section{Hasil dan Pembahasan}

\subsection{Diagram Usecase}

Usecase Diagram merupaka diagram yang digunakan untuk menggambarkan dan menjelaskan tentang bagaimana cara kerja dari sistem yang akan dibangun dilihat dari sudut pandang objek sebagai pengguna sistem [9]. Pada usecase ini juga dijelaskan kegiatan-kegiatan yang dilakukan oleh aktor sebagai penggunanya.

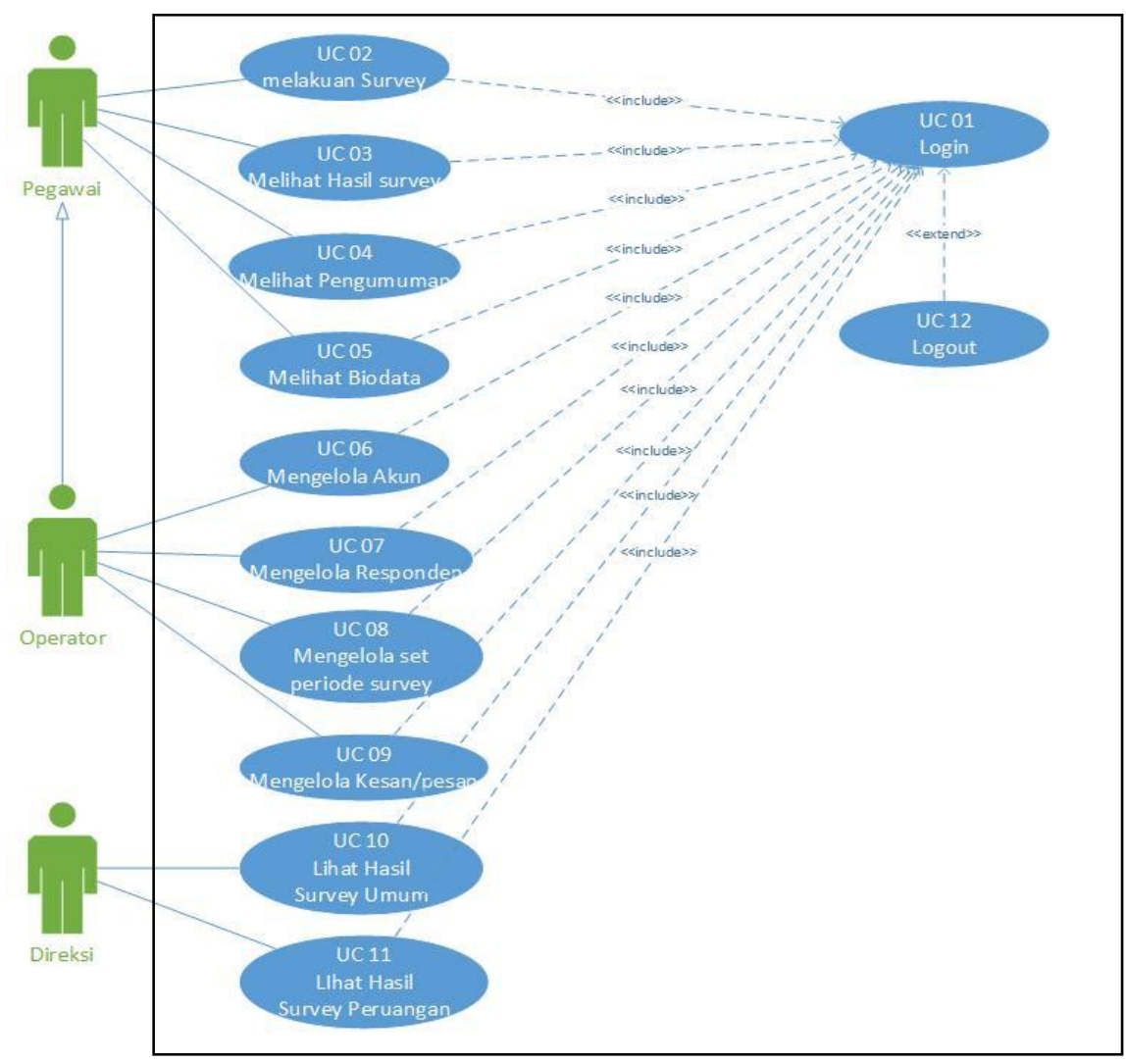

Gambar 1. Diagram Usecase

Pada usecase ini terdapat tiga actor yaitu pegawai, operator dan direksi. Operator dapat mengelola akun, data responden, pengaturan periode survey dan mengelola data pesan/kesan. Pegawai dapat melakukan survey, meihat hasi survey, melihat pengumuman dan melihat biodata sedangkan direksi hanya dapat melihat hasil survey umum dan hasil survey peruangan.

\subsection{Class Diagram}

Diagram kelas atau class diagram menggambarkan struktur sistem dari segi pendefinisian kelas-kelas yang akan dibuat untuk membangun sistem [10]. Class diagram merupakan diagram paling umum dipakai disemua pemodelan berorientasi objek. 


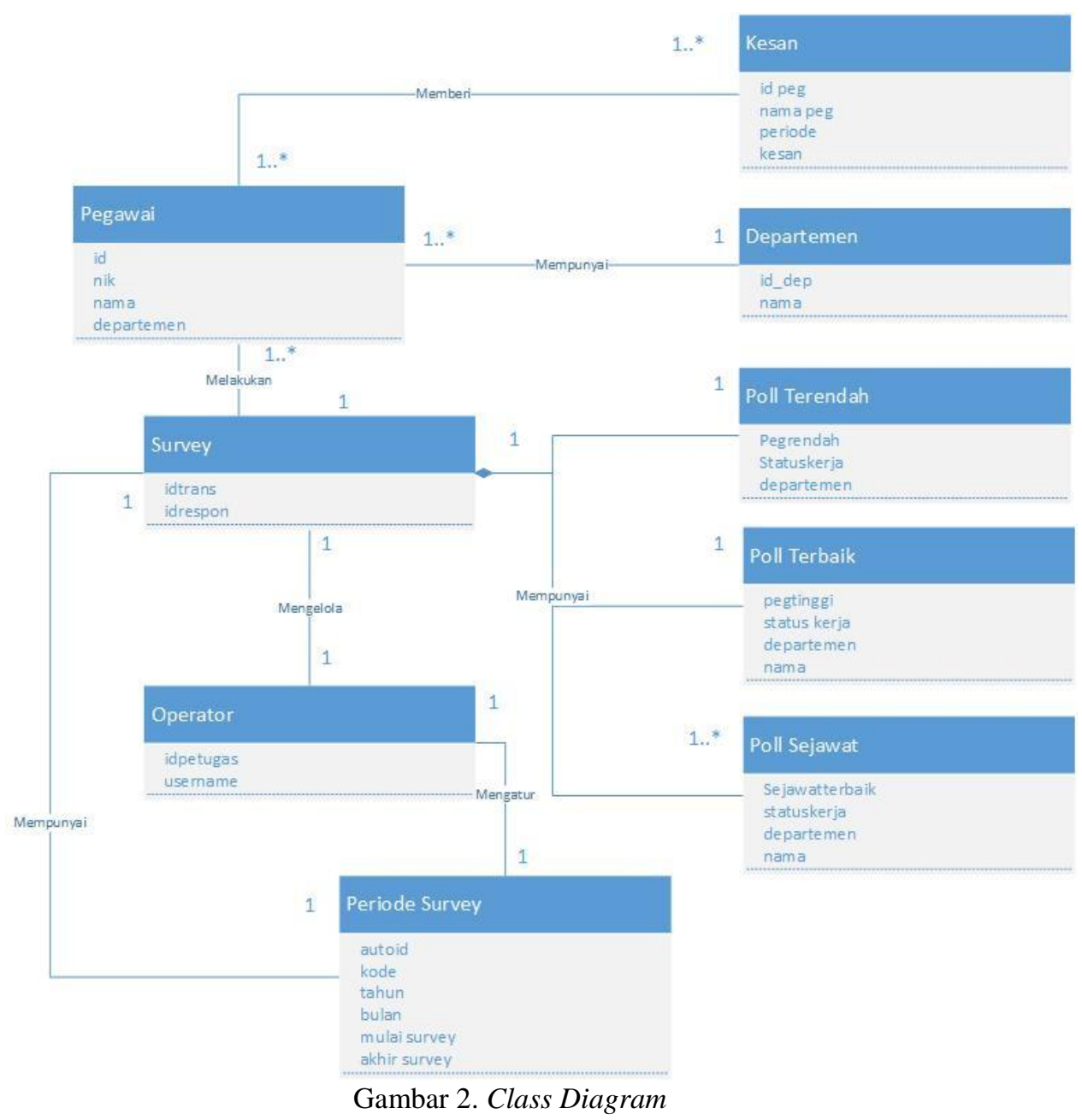

\subsection{Hasil Implementasi}

Implementasi adalah tahapan menterjemahkan rancangan kedalam aplikasi dengan menggunakan bahasa pemrograman.

1. Form Login

Tampilan form input login digunakan pada saat pertama kali user menjalankan aplikasi, maka yang pertama kali akan tampil adalah halaman menu login. Pertama-tama user harus memasukkan username dan password terlebih dahulu.

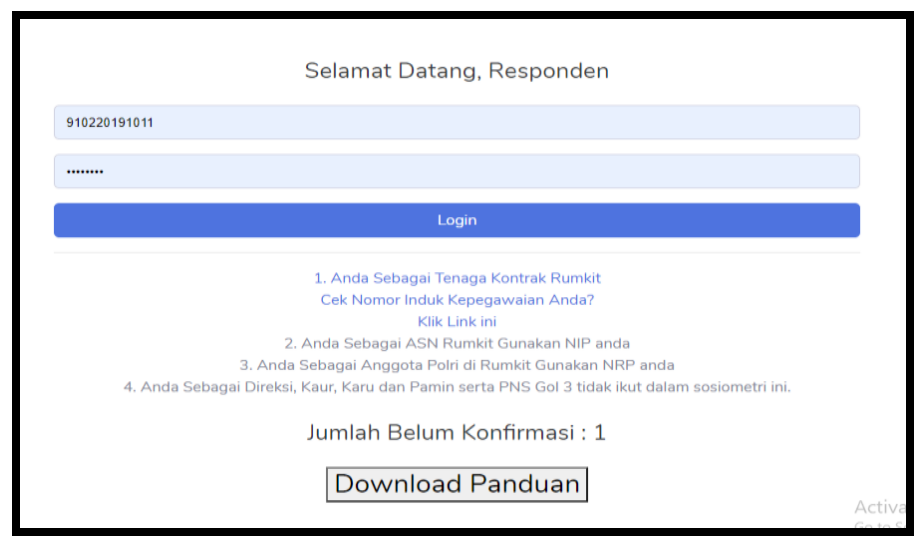

Gambar 3. Tampilan Login 
2. Menu Utama

Menu utama merupakan halaman utama yang menampilkan berbagai menu seperti menu biodata, menu data personal, menu lakukan voting serta menampilkan pengumuman dan testimony seperti pegawai terbaik bulan ini.

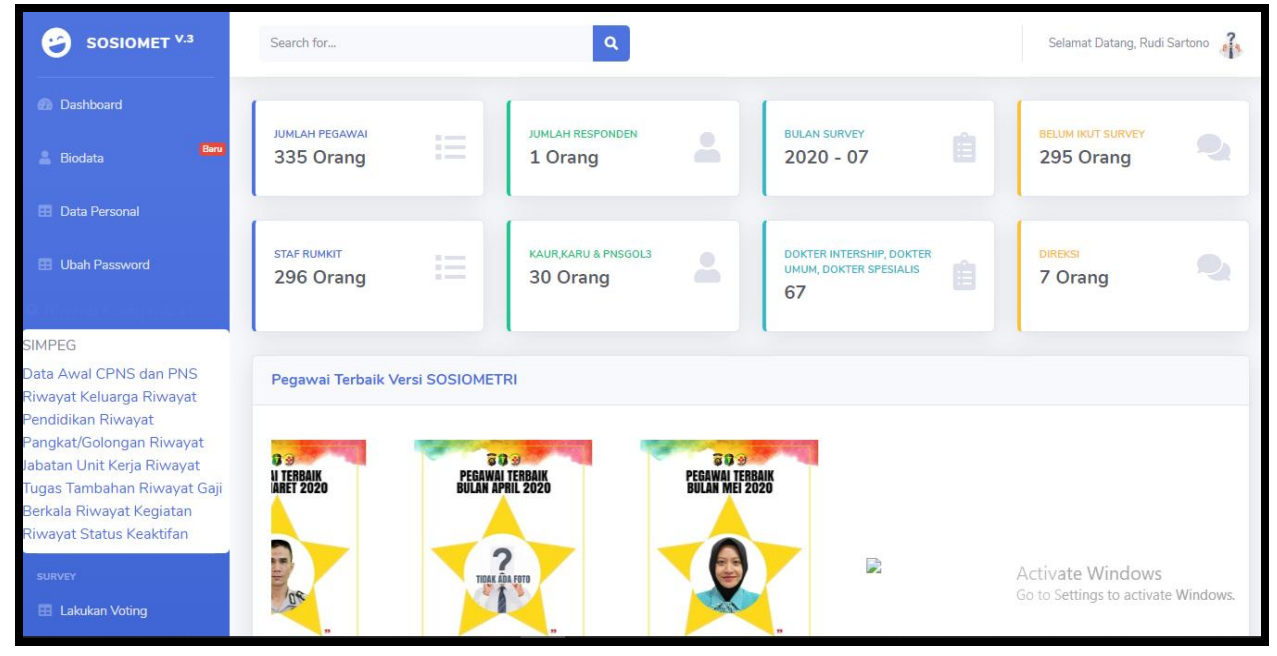

Gambar 4. Tampilan Menu Utama

3. Menu Survey Lakukan Voting

Menu Lakukan Voting merupakan menu yang digunakan untuk pemilihan pegawai dengan kategori terbaik dan belum baik tingkat rumah sakit serta kategori terbaik tingkat sejawat seruangan.

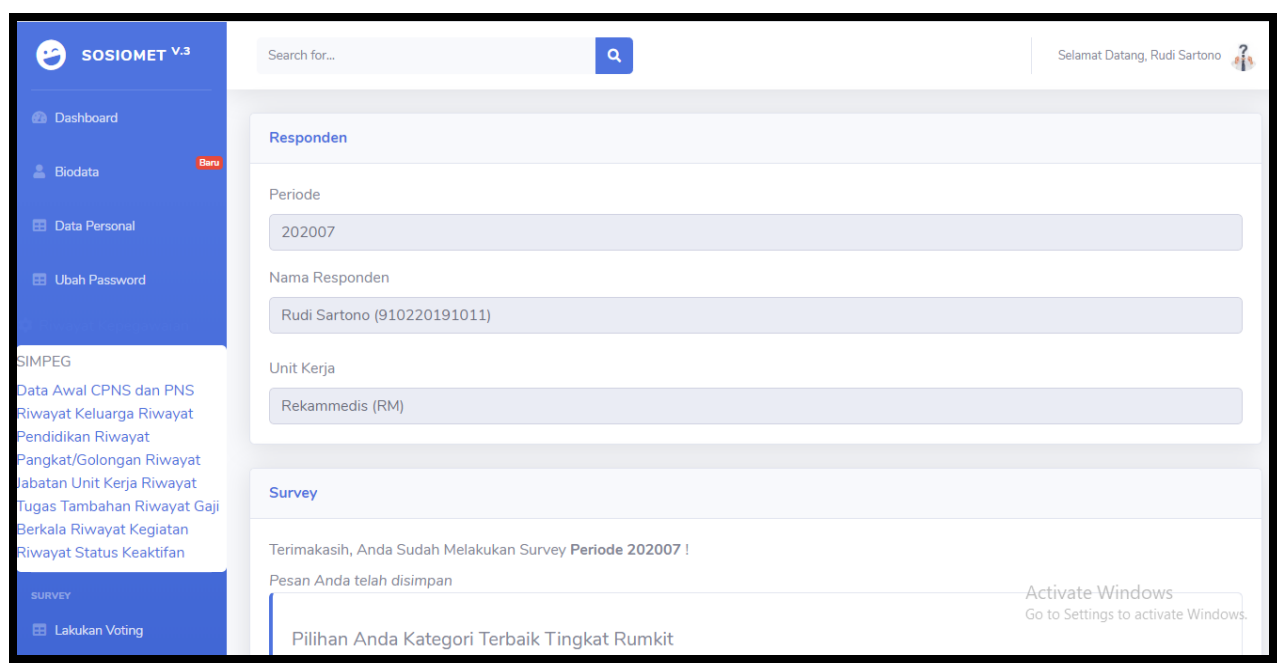

Gambar 5. Tampilan Menu Lakukan Voting

4. Menu Kesan/Pesan

Menu kesan/pesan merupakan menu yang digunakan untuk memberikan pesan dan kritik yang membangun kepada operator/direksi untuk perbaikan aplikasi sosiometri yang berkelanjutan. 


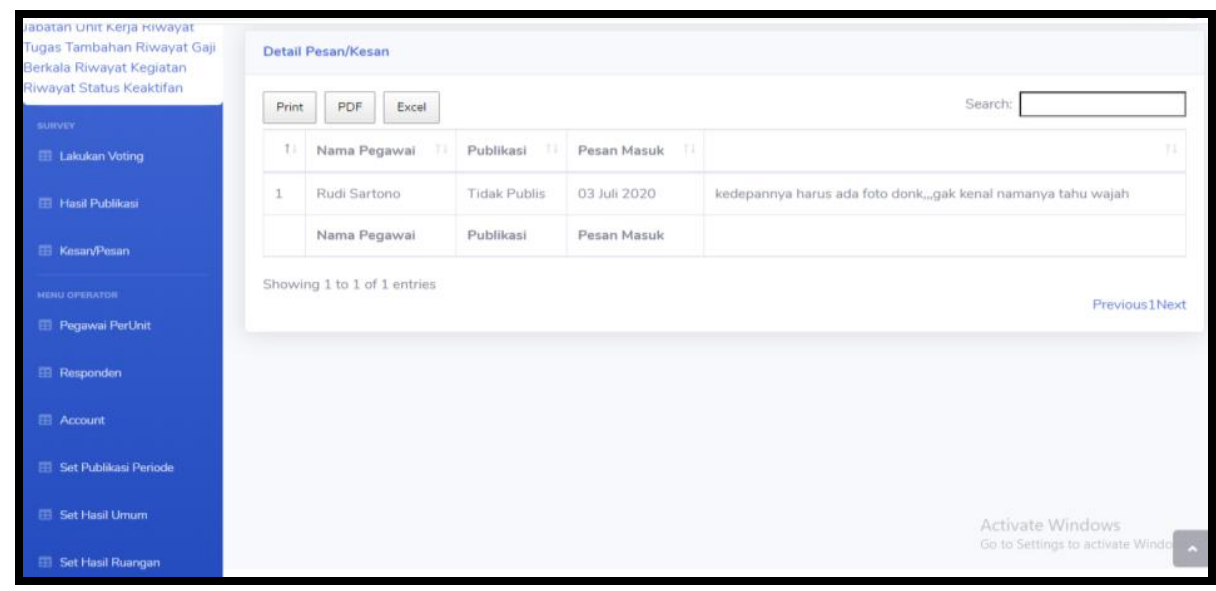

Gambar 6. Tampilan Menu Kesan/Pesan

5. Menu Pegawai Per Unit

Menu pegawai per unit merupakan menu yang digunakan oleh operator untuk melihat namanama pegawai yang belum memberi respon dan belum melakukan survey.

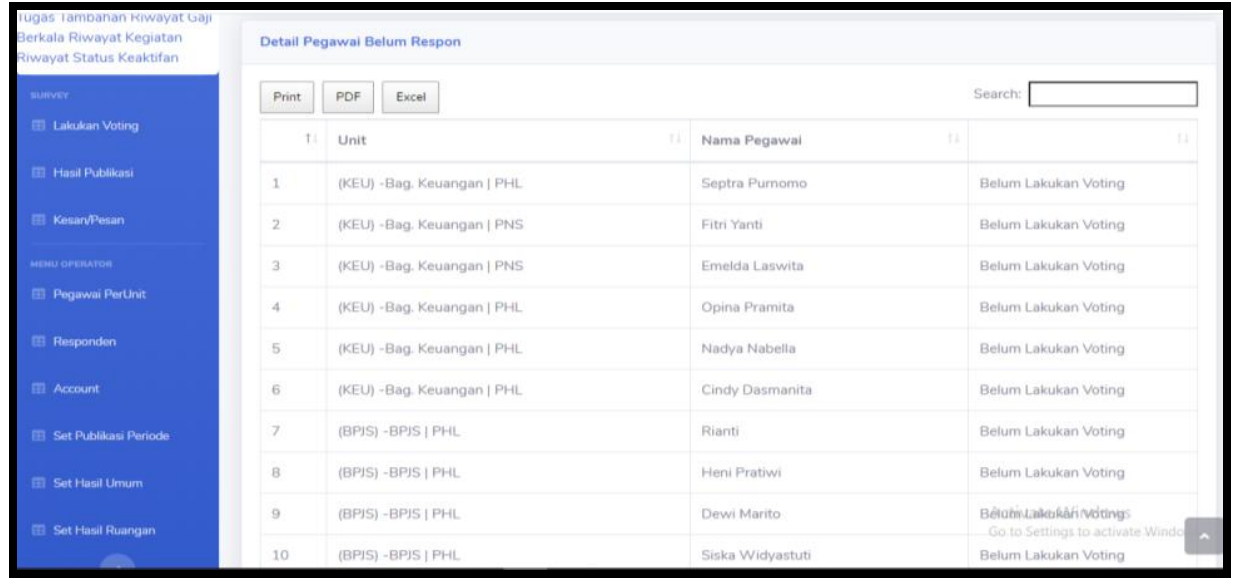

Gambar 7. Tampilan Menu Pegawai Per Unit

6. Menu Ubah Password

Menu ubah password merupakan menu yang digunakan oleh pegawai RS. Bhayangkara sebagai responden untuk mengubah password akun sosiometri.



Gambar 8. Tampilan Menu Ubah Password 
7. Menu Account Pegawai

Menu account pegawai merupakan menu yang digunakan oleh operator untuk mengelola data pegawai seperti data pegawai yang sudah aktivasi dan belum aktivasi didalam sosiometri

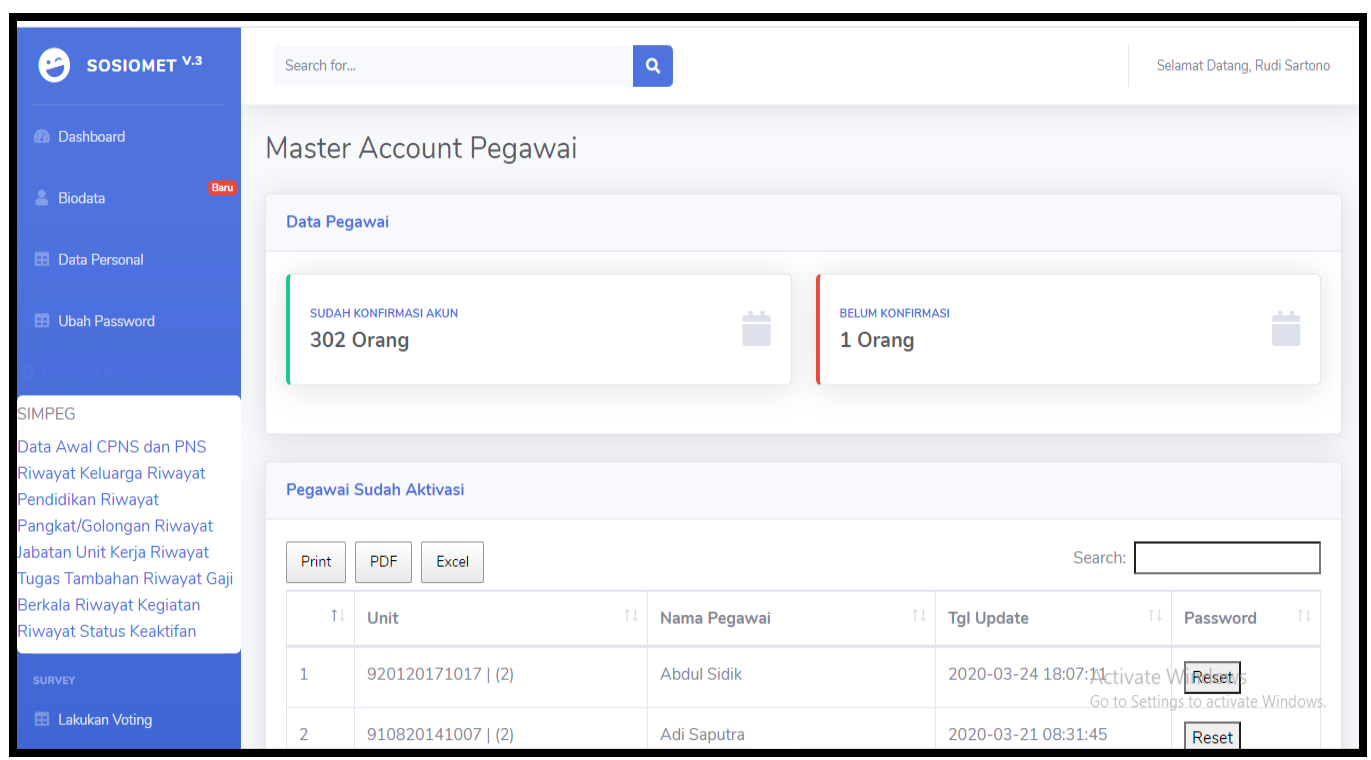

Gambar 9. Tampilan Menu Account Pegawai

8. Menu Responden

Menu responden adalah menu yang digunakan oleh operator untuk mengelola data responden sosiometri.



Gambar 10. Tampilan Menu Responden

\subsection{Hasil Pengujian}

Dari hasil pengujian dengan metode Black Box maka dapat dipastikan bahwa aplikasi yang dibuat telah sesuai dengannya dan dapat dipergunakan dengan baik tanpa ada kesalahan. Hasil pengujiannya dapat dilihat pada tabel berikut: 
Tabel 1. Pengujian Halaman Sosiometri

\begin{tabular}{|c|c|c|c|c|c|c|}
\hline No & Deskripsi & $\begin{array}{l}\text { Prosedur } \\
\text { Pengujian }\end{array}$ & Masukan & $\begin{array}{l}\text { Keluaran yang } \\
\text { diharapkan }\end{array}$ & $\begin{array}{l}\text { Hasil } \\
\text { Pengujian }\end{array}$ & Kesimpulan \\
\hline 1. & $\begin{array}{l}\text { Pengujian } \\
\text { menu login }\end{array}$ & $\begin{array}{l}\text { - Buka } \\
\text { aplikasi } \\
\text { sosiometri }\end{array}$ & $\begin{array}{l}\text { - Input nik dan } \\
\text { password } \\
\text { - Klik tombol } \\
\text { login }\end{array}$ & $\begin{array}{l}\text { Sistem } \\
\text { menampilkan } \\
\text { halaman utama } \\
\text { sosiometri }\end{array}$ & Sesuai & Valid \\
\hline 2. & $\begin{array}{l}\text { Pengujian } \\
\text { menambah } \\
\text { data pada } \\
\text { menu } \\
\text { lakukan } \\
\text { voting }\end{array}$ & $\begin{array}{l}\text {-Login } \\
\text { - Klik menu } \\
\text { lakukan } \\
\text { voting }\end{array}$ & $\begin{array}{l}\text { - Pilih kategori } \\
\text { terbaik } \\
\text { tingkat } \\
\text { rumkit } \\
\text { - Pilih kategori } \\
\text { belum baik } \\
\text { tingkat } \\
\text { rumkit } \\
\text { - Pilih kategori } \\
\text { terbaik } \\
\text { tingkat } \\
\text { sejawat } \\
\text { seruangan } \\
\end{array}$ & $\begin{array}{l}\text { Data pada } \\
\text { database } \\
\text { bertambah dan } \\
\text { menampilkan } \\
\text { pesan bahwa data } \\
\text { berhasil ditambah }\end{array}$ & Sesuai & Valid \\
\hline 3. & $\begin{array}{l}\text { Pengujian } \\
\text { menu } \\
\text { pegawai } \\
\text { per unit }\end{array}$ & $\begin{array}{l}\text { - Login } \\
\text { - Klik menu } \\
\text { pegawai per } \\
\text { unit }\end{array}$ & $\begin{array}{l}\text { - Pilih unit } \\
\text { kerja } \\
\text { - Pilih periode }\end{array}$ & $\begin{array}{l}\text { Sistem } \\
\text { menampilkan } \\
\text { daftar data } \\
\text { pegawai yang } \\
\text { belum } \\
\text { memberikan } \\
\text { respon tiap } \\
\text { unitnya }\end{array}$ & Sesuai & Valid \\
\hline 4. & $\begin{array}{l}\text { Pengujian } \\
\text { menu ubah } \\
\text { password }\end{array}$ & $\begin{array}{l}\text { - Login } \\
\text { - Klik menu } \\
\text { ubah } \\
\text { password }\end{array}$ & $\begin{array}{l}\text { - Input } \\
\text { password } \\
\text { baru } \\
\text { - Input } \\
\text { konfirmasi } \\
\text { password } \\
\text { - Klik tombol } \\
\text { simpan }\end{array}$ & $\begin{array}{l}\text { Sistem } \\
\text { menampilkan } \\
\text { pesan password } \\
\text { berhasil di ubah }\end{array}$ & Sesuai & Valid \\
\hline
\end{tabular}

\section{Kesimpulan}

Dengan adanya aplikasi sosiometri maka seorang pegawai dapat menilai rekan kerjanya tanpa diketahui karena penilaian bersifat rahasia. Dengan aplikasi sosiometri divisi sumber daya manusia dapat menilai kinerja pegawai dari sisi hubungan antar individu dan untuk memberikan motivasi kepada pegawai untuk bekerja dan berinteraksi dengan baik serta membantu pimpinan mengatasi konflik internal antar pegawai. Untuk penelitian kedepan aplikasi sosiometri dapat dikembangkan menjadi lebih lengkap dengan menambahkan beberapa fitur seperti penilaian kinerja dari sisi integritas dan kompetensi pegawai.

\section{Daftar Rujukan}

[1] E. Susanto and U. M. Metro, "Tutorial to Use Agna Sociometry," no. November 2013, 2013, doi: 10.13140/RG.2.1.4853.4481.

[2] S. Nur Hadi and A. Juliani Noor, "Keefektifan Kelompok Belajar Siswa Berdasarkan Sosiometri dalam Menyelesaikan Soal Cerita Matematika di SMP,” EDU-MAT J. Pendidik. Mat., vol. 1, no. 1, pp. 60-67, 2013, doi: 10.20527/edumat.v1i1.564.

[3] R. W. Nita and A. Zaini, "Analisis Aplikasi Sosiometri Untuk Pengungkapan Interpersonal Skill (Solusi yang Ditawarkan Menuju Profesionalisme Guru BK)," J. Ilm. Dalam Implementasi Kurikulum Bimbing. Dan Konseling, pp. 4-6, 2017.

[4] I. W. P. Suyana, "Pengembangan Aplikasi Analisis Kuisioner Sosiometri Tipe Normatif Untuk SMA Berbasis WEB,” Karmapati, vol. 2, no. 1, p. 2013, 2013. 
[5] A. T. Rumiyati, “Konsep Dasar Sosiometri," Modul, pp. 1-22, 2015.

[6] O. Eri Purwanti and E. Purnomo, "Pengembangan Instrumen Keterampilan Sosial Berbasis Observasi Dan Sosiometri Dalam Pembelajaran Ips,” Jurnal.Fkip.Unila.Ac.Id, no. 1, 2015.

[7] W. B. . Rochani, Dalimunthe R. Z, "Penggunaan Software Sosiometri Untuk Eksplorasi Kematangan Sosial Pada Mata Kuliah Asesment Non Tes," J. Penelit. Bimbing. dan Konseliing, vol. 4, no. 1, 2019, doi: 10.1017/CBO9781107415324.004.

[8] A. Harum, "Pengembangan Program Sosiometri Sebagai Media Pengungkapan Hubungan Sosial Siswa Sman 9 Makassar," J. Psikol. Pendidik. dan Konseling J. Kaji. Psikol. Pendidik. dan Bimbing. Konseling, vol. 1, no. 2, p. 105, 2015, doi: 10.26858/jpkk.v1i2.1539.

[9] M. Shalahuddin, \& Rosa, A. S., “Analisis dan Desain Sistem Informasi”. Bandung : Politeknik Telkom, 2008.

[10] S. Dharwiyanti, \& R. S. Wahono, "Pengantar Unified Modeling Language (UML)". Ilmu Komputer, $1-13,2003$. 